\title{
Settlement characteristics of the foundation with a top sand layer and an underlying muck layer treated with three methods
}

\author{
Shiyang $\mathrm{Li}^{\mathrm{i}}$, Xin Huang ${ }^{\text {ii) }}$, Yin Cheng ${ }^{\text {i) }}$ and $\mathrm{Hao} \mathrm{Yu}^{\text {i) }}$
}

\begin{abstract}
i) Ph.D Student, School of Transportation Science and Engineering, Beihang University, 37 Xueyuan Road, Beijing, China. ii) Professor, School of Transportation Science and Engineering, Beihang University, 37 Xueyuan Road, Beijing, China.
\end{abstract}

\begin{abstract}
A high speed railway foundation with a thick top sand layer overlying a thick muck layer was treated with three methods respectively: both the sand layer and muck layer being treated by pre-stressed concrete pipe pile with a geogrid on pile top (PP foundation), only the muck layer being treated by jet grouting pile (JP foundation), and the sand layer being treated by dynamic compaction (DC foundation). Based on in-suit test data measured during construction of the railway embankment, settlement characteristics of the foundation were analyzed. The results show that when choosing treatment method, not only the load level and foundation geological feature should be paid attention to, but also treatment aim must be considered; treatment method suitable for buildings to control total settlement might not be effective for embankment only to control post-construction settlement (PCS). DC foundation could only eliminate settlement of the sand within effective depth of dynamic compaction treating, so it was not suitable for the case whose treatment aim was controlling PCS. JP foundation, whose settlement during construction was large while the PCS was close to that of PP foundation, was efficient for the case with treatment aim of controlling PCS but might not be effective for the case that needs to control total settlement. PP foundation, whose settlement during construction and PCS were both small, as compared with JP foundation, just increased the project cost by increasing pile length to treat the sand layer for controlling PCS, and whose long-term stability of settlement depending on the durability of the geogrid is less reliable because the sand layer still remained loose.
\end{abstract}

Keywords: top sand layer, underlying muck layer, foundation treatment, settlement characteristics

\section{INTRODUCTION}

For a $200 \mathrm{~km} / \mathrm{h}$ high speed railway in Guangdong Province of China, the foundation with a geological feather that a top thick sand layer overlies a thick muck layer, in order to control only post-construction settlement (PCS, embankment settlement occurred after the embankment construction is finished and the railway track laying begins), three methods were adopted to treat the foundation in three sections respectively: both the sand layer and muck layer being treated by pre-stressed concrete pipe pile, only the muck layer being treated by jet grouting pile, and the sand layer being treated by dynamic compaction.

For layered foundation, such topics were studied that bearing capacity (Shiau et al, 2003), the effect of geogrid on improving bearing capacity and reducing settlement (Demir et al, 2012), the effect of stiffness of a deep deposit on the compression of the overlying subgrade layer (Khamis, 2003), and stress distributing characteristics and the effect of overlying crust layer on stress dispersion (Wen, 2007), while for the foundation with a top sand layer overlying a muck layer, settlement characteristics of the foundation treated with different method has not been reported.

In this study, based on in-situ test data measured during construction of the railway embankment, settlement characteristics of the foundation treated with three methods were analysed.

\section{GENERAL SITUATION OF THE PROJECT}

The high speed railway was located in littoral alluvial plain. The subsoil profile consists mainly of four sublayers: sublayer I (loose fine sand, 11 14m thick, $\quad \gamma_{\mathrm{t}}=18.0 \mathrm{kN} / \mathrm{m}^{3}$, Young's modulus $=27 \mathrm{MPa}$ ), sublayer II (medium dense sand, 2 9m thick, $\gamma_{\mathrm{t}}=18.0 \mathrm{kN} / \mathrm{m}^{3}$, Young's modulus $=30 \mathrm{MPa}$ ), sublayer III (brown muck, $6 \sim 14 \mathrm{~m}$ thick, $\gamma_{\mathrm{t}}=16.7 \mathrm{kN} / \mathrm{m}^{3}$, water content $\mathrm{w}=54.8 \%$, initial void ratio $\mathrm{e}_{0}=1.72$, undrained shear strength $c=12 \mathrm{kPa}, \quad \varphi=6.7^{\circ}$ ), and sublayer IV (dense sand, $4 \sim 8 \mathrm{~m}$ thick, $\gamma_{\mathrm{t}}=20.0 \mathrm{kN} / \mathrm{m}^{3}$, Young's modulus $=50 \mathrm{MPa}$ ). The ground water level is about $2.0 \mathrm{~m}$ below the ground surface. The general conditions of the treated foundation in three sections are shown in Table 1 , and the representative profile (section 1) is shown in Fig.1.

In section 1, pre-stressed concrete pipe pile (PP) 
was adopted to treat both the sand layer I \& II and muck layer III (PP foundation), and the piles, outer diameter $0.5 \mathrm{~m}$, inner diameter $0.4 \mathrm{~m}$ and length $29.0 \mathrm{~m}$, were square arrangement with an interval $2.2 \mathrm{~m}$, and one layer of geogrid placed on top of the piles. In section 2, jet grouting pile (JP) was adopted to treat only the muck layer III (JP foundation), and the piles, diameter $0.8 \mathrm{~m}$ and length $14.0 \mathrm{~m}$, were triangular arrangement with an interval $2.4 \mathrm{~m}$, and one layer of geogrid placed on the ground surface. In section 3, dynamic compaction (DC) was adopted to treat sand layer I (DC foundation), six passes of impact were conducted; in the former four passes, tamping was exerted on the impact points; in the last two passes, the whole of the impacted zone was tamped, and impact energy input reached $1500 \mathrm{kN} \cdot \mathrm{m}$ per drop; 12 points were selected randomly to check by cone penetration test, and the results are shown in Table 2.

The test items are shown in Table 1, and the layout of measurement devices in section 1 are presented in Fig.1. Settlement measurement device contained a PVC pipe and settlement rings, and settlement gauge (JMZX-1006, made in China) was used to measure layered settlement. Earth pressure cells which were set only in PP foundation, were embedded on both the pile top and the soil in the center of four neighboring piles, and vibrating wire earth pressure cell (measuring range $0 \sim 0.6 \mathrm{MPa}$, made in China) was used to measure earth pressure. The testing was conducted in accordance with the Chinese Technical Code (YS 5229-1996).

Table 1 General conditions of the treated foundation at three sections

\begin{tabular}{|c|c|c|c|c|c|}
\hline Sections & Treatment methods & $\begin{array}{l}\text { Start-stop depth of } \\
\text { treated zone }(\mathrm{m})\end{array}$ & $\begin{array}{l}\text { Start-stop depth of soil } \\
\text { layers }(\mathrm{m})\end{array}$ & $\begin{array}{l}\text { Embankment height } \\
\text { (m) }\end{array}$ & Test items \\
\hline Section 1 & PP & $0-29$ & $\begin{array}{cl}\text { I :0-11 } & \text { II :11-13 } \\
\text { III:13-27 } & \text { IV :27-33 }\end{array}$ & 6.13 & $\begin{array}{l}\text { Layered settlement } \\
\text { Earth pressure }\end{array}$ \\
\hline Section 2 & JP & $15-29$ & $\begin{array}{cc}\text { I }: 0-11 & \text { II }: 11-17 \\
\text { III }: 17-27 & \text { IV }: 27-33\end{array}$ & 6.61 & Layered settlement \\
\hline Section 3 & DC & $0-6.6$ & $\begin{array}{cc}\text { I :0-14 } & \text { II }: 14-20.5 \\
\text { III:20.5-27 } & \text { IV }: 27-33\end{array}$ & 4.12 & Layered settlement \\
\hline
\end{tabular}

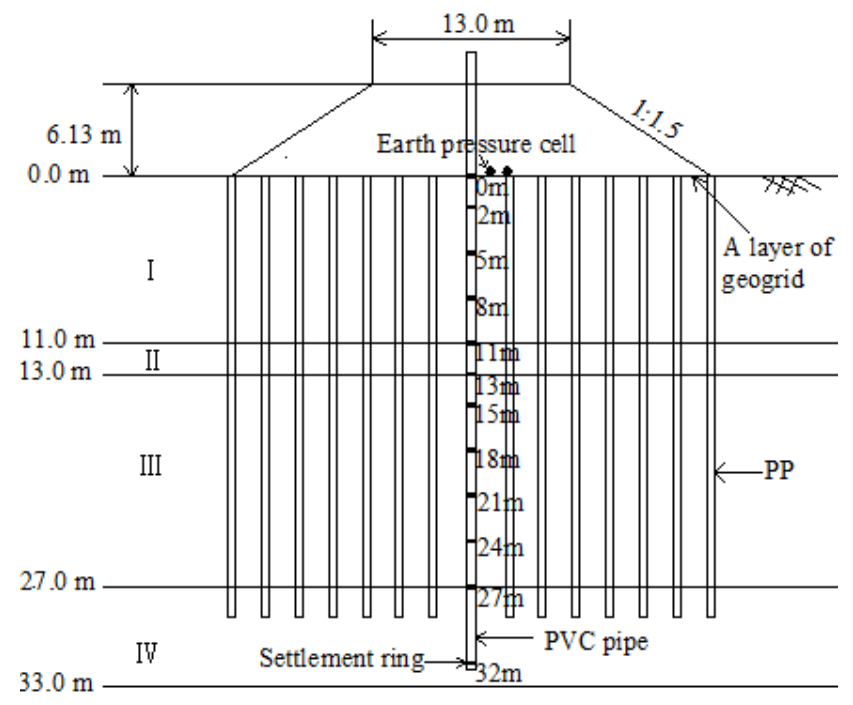

Fig.1 Representative profile (Section 1)

Table 2 Cone penetration test results of DC foundation

\begin{tabular}{lllll}
\hline \multirow{2}{*}{ Depth/m } & \multicolumn{3}{c}{ Bearing capacity $(\mathrm{kPa})$} & \multicolumn{2}{l}{ Young's modulus $(\mathrm{kPa})$} \\
\cline { 2 - 5 } & $\begin{array}{l}\text { Before } \\
\text { treatment }\end{array}$ & $\begin{array}{l}\text { After } \\
\text { treatment }\end{array}$ & $\begin{array}{l}\text { Before } \\
\text { treatment }\end{array}$ & $\begin{array}{l}\text { After } \\
\text { treatment }\end{array}$ \\
\hline $0-0.5$ & 121 & 124.3 & 15,000 & 32,000 \\
$0.5-1.4$ & 180 & 251.5 & 24,000 & 68,000 \\
$1.4-3.8$ & 160 & 209.7 & 27,000 & 60,000 \\
$3.8-6.6$ & 239 & 254.7 & 31,000 & 68,000 \\
$6.6-9.0$ & 205 & 204.9 & 27,000 & 27,000 \\
\hline
\end{tabular}

\section{RESULTS AND ANALYSIS}

Figs.2, 4 and 5 show layered settlement of PP foundation, JP foundation, and DC foundation respectively. Fig. 3 shows pile stress $\left(\sigma_{\mathrm{p}}\right)$, soil stress $\left(\sigma_{\mathrm{s}}\right)$ and pile-soil stress ratio $\left(\sigma_{\mathrm{p}} / \sigma_{\mathrm{s}}\right)$ of PP foundation. Settlement characteristics during embankment construction are summarized in Table 3 , where $\Delta \mathrm{P}_{1}$ refers to the stage that load increased from 0 to $35 \%$ of total embankment load, $\Delta \mathrm{P}_{2}$ refers to the stage that load increased from $65 \%$ to $100 \%$ of total embankment load, $\Delta \mathrm{S} / \mathrm{S}$ refers to the percent of each stage settlement accounting for $\mathrm{S}_{1}$, and $\Delta \mathrm{S} / \Delta \mathrm{P}$ refers to the settlement induced by unit load.

Both $S_{1}$ and $S_{2}$ are also summarized in Table 3, where $S_{1}$ represents the measured values of settlement during construction, $S_{2}$ represents the values of PCS calculated by modified hyperbolic method which is commonly used in Guangdong Province of China to predict post-construction settlement of high speed railway on soft ground ( $\mathrm{Li}$ et al, 2008).

Table 3 Settlement characteristics

\begin{tabular}{|c|c|c|c|c|c|c|}
\hline \multirow{2}{*}{$\begin{array}{l}\text { Treatment } \\
\text { methods }\end{array}$} & \multicolumn{2}{|l|}{$\Delta \mathrm{P}_{1}$} & \multicolumn{2}{|l|}{$\Delta \mathrm{P}_{2}$} & \multirow{2}{*}{$\frac{S_{1}}{(\mathrm{~mm})}$} & \multirow{2}{*}{$\frac{\mathrm{S}_{2}}{(\mathrm{~mm})}$} \\
\hline & $\begin{array}{l}\Delta \mathrm{S} / \mathrm{S} \\
(\%)\end{array}$ & $\begin{array}{l}\Delta \mathrm{S} / \Delta \mathrm{P} \\
(\mathrm{mm} / \mathrm{kPa})\end{array}$ & $\begin{array}{l}\Delta \mathrm{S} / \mathrm{S} \\
(\%)\end{array}$ & $\begin{array}{l}\Delta \mathrm{S} / \Delta \mathrm{P} \\
(\mathrm{mm} / \mathrm{kPa})\end{array}$ & & \\
\hline PP & 73 & 0.52 & 8 & 0.05 & 26 & 9 \\
\hline JP & 51 & 0.84 & 16 & 0.26 & 72 & 20 \\
\hline $\mathrm{DC}$ & 20 & 0.57 & 44 & 0.82 & 61 & 106 \\
\hline
\end{tabular}

For PP foundation, settlement increased with load increasing during $\Delta \mathrm{P}_{1}$, but both $\Delta \mathrm{S} / \mathrm{S}$ and $\Delta \mathrm{S} / \Delta \mathrm{P}$ reduced substantially during $\Delta \mathrm{P}_{2}$; when embankment fill was completed, the settlement became stable rapidly, settlement deformation of each soil layer varied uniformly with depth increasing; $\sigma_{\mathrm{p}} / \sigma_{\mathrm{s}}$ increased with load increasing during early loading stage of embankment fill; during later stage, $\sigma_{\mathrm{s}}$ was almost 
stable while $\sigma_{\mathrm{p}}$ kept increasing substantially.

The phenomenon above indicates that the pile and geogrid formed pile-net structure, and the stress induced by embankment fill concentrated gradually on the pile, so settlement was mainly controlled by the pile. Therefore, both the settlement during construction and PCS were fair small.

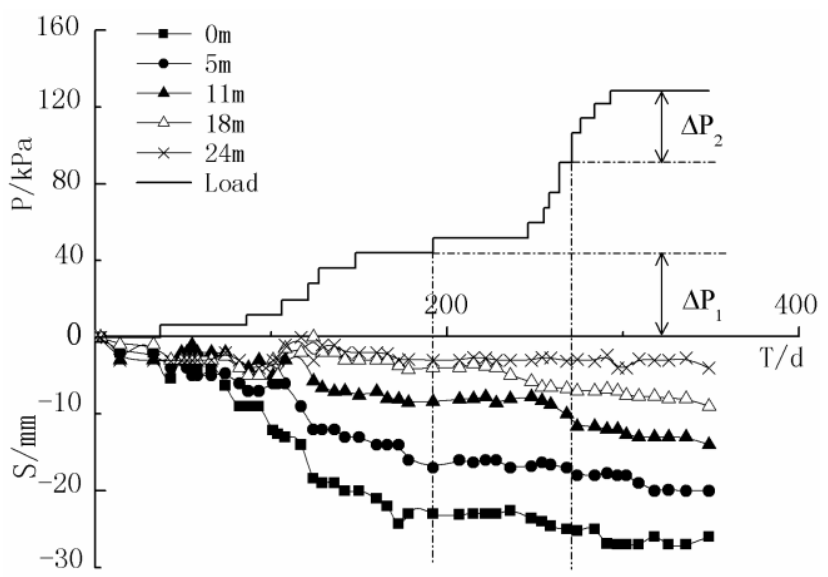

Fig. 2 Curves of layered settlement of PP foundation

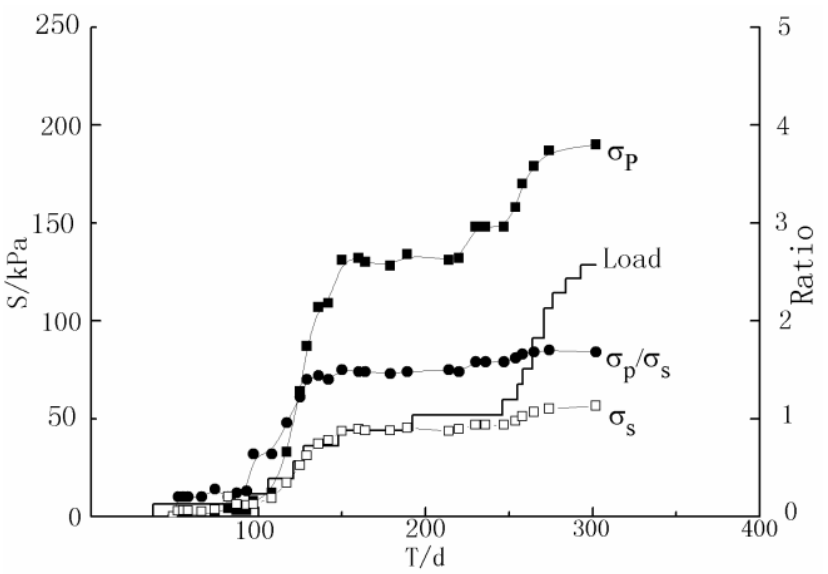

Fig. 3 Curves of pile stress, soil stress and stress ratio

For JP foundation, because the top sand layer was not treated, both $\Delta \mathrm{S} / \mathrm{S}$ and $\Delta \mathrm{S} / \Delta \mathrm{P}$ were rather large during $\Delta \mathrm{P}_{1}$. As early loading of embankment fill preloaded the sand and improved its deformation modulus and bearing capacity, which help to reduce settlement during subsequent loading; the muck layer was treated by JP, which formed composite foundation and produced very little settlement; so both $\Delta \mathrm{S} / \mathrm{S}$ and $\Delta \mathrm{S} / \Delta \mathrm{P}$ became fairly small during $\Delta \mathrm{P}_{2}$. The settlement became stable rapidly after embankment fill completed; during the whole process of embankment fill, the settlement occurred mainly in the sand layer. During the loading stage of the last two layers of embankment fill, the settlement curves between depth $0 \mathrm{~m}$ and $17 \mathrm{~m}$ were nearly parallel, which indicated that settlement of the sand layer was almost completed, so the sand layer became dense and would produce very little PCS.

For DC foundation, during $\triangle \mathrm{P} 1$ additional stress induced by embankment fill was mainly confined within effective depth of $\mathrm{DC}$ treating, so $\Delta \mathrm{S} / \Delta \mathrm{P}$ was significantly less than that of JP foundation. During subsequent loading, the additional stress gradually affected deeper sand and the muck layer and made them subsided evidently, so both $\Delta \mathrm{S} / \mathrm{S}$ and $\Delta \mathrm{S} / \Delta \mathrm{P}$ increased remarkably during $\Delta \mathrm{P}_{2}$. The settlement kept increasing substantially after embankment fill completed; during the loading stage of the last two layers of embankment fill, the settlement curves between depth $0 \mathrm{~m}$ and $16.5 \mathrm{~m}$ were nearly parallel, which indicated that settlement of the sand layer was almost completed. Settlement of the muck layer couldn't be stable for quite a long time, which would lead to large PCS. Compressive deformation between depth $0 \mathrm{~m}$ and $8 \mathrm{~m}$ was much smaller than that of JP foundation under equal load, which showed the effect of DC.

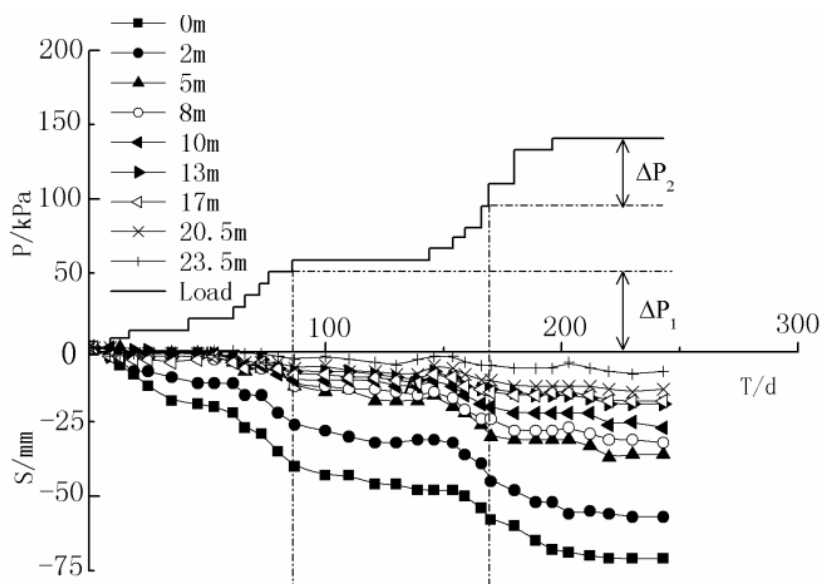

Fig.4 Curves of layered settlement of JP foundation

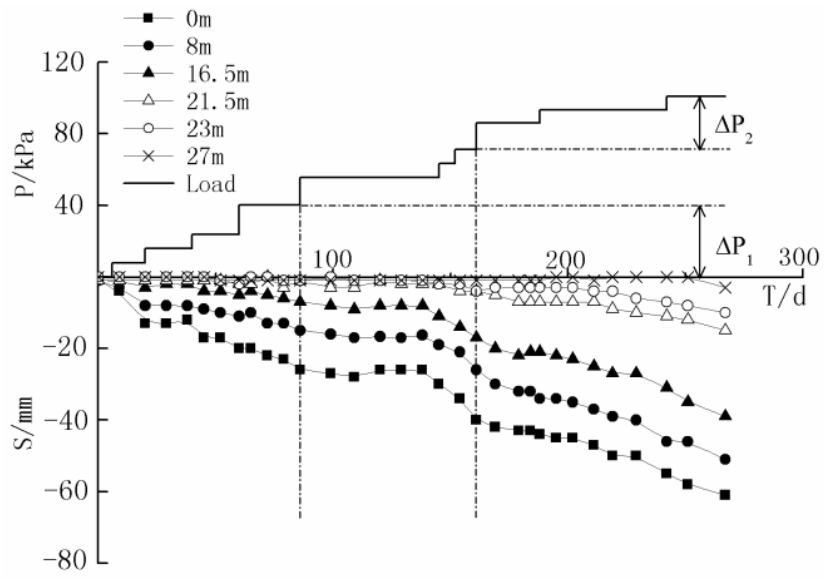

Fig.5 Curves of layered settlement of DC foundation

\section{SETTLEMENT CHARACTERISTICS}

When choosing treatment method, not only the load level and foundation geological feature should be paid attention to, but also treatment aim must be considered. For a certain foundation, the treatment method that is suitable for buildings which need to control total settlement might not be effective for embankment that 
needs to control PCS only.

For the foundation with a top loose sand layer overlying a muck layer, the loose sand layer produced large settlement during construction, but became stable rapidly, and has very little effect on PCS; while the muck layer couldn't be stable for quite a long time, and produced large settlement during construction and PCS.

Treating such foundation by DC, the settlement of the sand within effective depth of DC treating could be reduced, as above test results shown, compressive deformation between depth $0 \mathrm{~m}$ and $8 \mathrm{~m}$ under equal load level and settlement during construction were much smaller than those of JP foundation whose top sand layer was not treated. But if controlling PCS is concerned, DC treating is not suitable. Because, on the one hand, DC treating has very little effect on the underlying muck layer; on the other hand, the fact that the settlement curves at depth $0 \mathrm{~m}$ and $16.5 \mathrm{~m}$ were nearly parallel during last stage of embankment fill indicated that settlement of not only the sand within effective depth of DC treating but also the sand beyond the effective depth had been almost completed, which implied that DC just did what could be done also by embankment fill itself. Therefore DC is a useful foundation treatment method to control total settlement.

The feature of JP foundation was that settlement during construction was the largest among the three; but, because settlement of the sand layer was almost finished and the muck layer formed a composite foundation, the PCS was similar to that of PP foundation. For embankment that needs to control PCS only, the treatment should focus on the muck layer. Treating only the muck layer by JP grasped correctly the project feature of both the treatment aim and geological condition, which made PCS of JP foundation small enough. But for the case that needs to control total settlement, JP foundation might not be effective.

For PP foundation, both the settlement during embankment construction and PCS were small. But from the view of controlling PCS, as compared with JP foundation, by increasing pile length to treat the sand layer, PP foundation achieved no substantial effect but just increased the project cost.

Besides, for PP foundation, the pile and geogrid formed pile-net structure which bored most of the load of embankment fill. This treatment method took embankment fill as the weight just causing settlement only, but neglected that the loading of embankment fill could also make the top sand layer dense. The top sand layer of JP foundation became a dense one due to the loading of embankment fill, while that of PP foundation still remained loose, the proof of which can be seen in Figs. 2 and 4 where compressive deformation of the top sand layer of PP foundation was much smaller than that of JP foundation. Therefore, long-term stability of settlement of PP foundation would depend on the durability of the geogrid. If the geogrid failed working under the long-term effect of repeated railway traffic load, large additional settlement would be produced. Therefore, as far as long-term stability of settlement is concerned, PP foundation is less reliable than JP foundation.

\section{CONCLUSIONS}

1) When choosing treatment method, not only the load level and foundation geological feature should be paid attention to, but also treatment aim must be considered. For the foundation with a top sand layer overlying a muck layer, treatment method that is suitable for buildings which need to control total settlement might not be effective for embankment that needs only to control post-construction settlement.

2) DC foundation could only eliminate settlement of the sand within effective depth of dynamic compaction, so it was not suitable for the case whose treatment aim was controlling post-construction settlement.

3) JP foundation, whose settlement during construction was rather large but post-construction settlement was close to that of PP foundation, was efficient for the case whose treatment aim was controlling post-construction settlement.

4) PP foundation, both settlement during construction and post-construction settlement of which were small. But from the view of economy, it was not as efficient as JP foundation for controlling post-construction settlement. Besides, long-term stability of settlement of PP foundation would depend on the durability of the geogrid as the top sand layer still remained loose, and is less reliable than JP foundation.

\section{REFERENCES}

1) Demir, A., Laman, M., Yildiz, A. and Ornek, M. (2012): Large scale field tests on geogrid-reinforced granular fill underlain by clay soil, Geotextiles and Geomembranes, 38, $1-15$.

2) Khamis E. (2003): Compression of a Thin Layer Overlying Deep Soil Deposit, Master thesis, Concordia University, Montreal, Canada.

3) Li, J. F., Mo, H. H., Li, X. and Xu, X. Q. (2008): Two new methods of settlement prediction, Chinese Journal of Geotechnical Engineering, 29 (1), 140-144.

4) Shiau, J. S., Lyamin, A. V. and Sloan, S. W. (2003): Bearing capacity of a sand layer on clay by finite element limit analysis, Canadian Geotechnical Journal, 40 (5), 900-915.

5) TB 10035-2006. (2006): Code for design on special subgrade of railway, Industry Standard of the People's Republic of China (in Chinese).

6) Wen, Y. X. (2007): The research work about the bearing capacity and deformation characteristic of two-layered ground, D.Phil. Thesis, Tongji University, Shanghai, China.

7) YS 5229-1996. (1996): Code for monitoring of geotechnical engineering, Industry Standard of the People's Republic of China (in Chinese). 